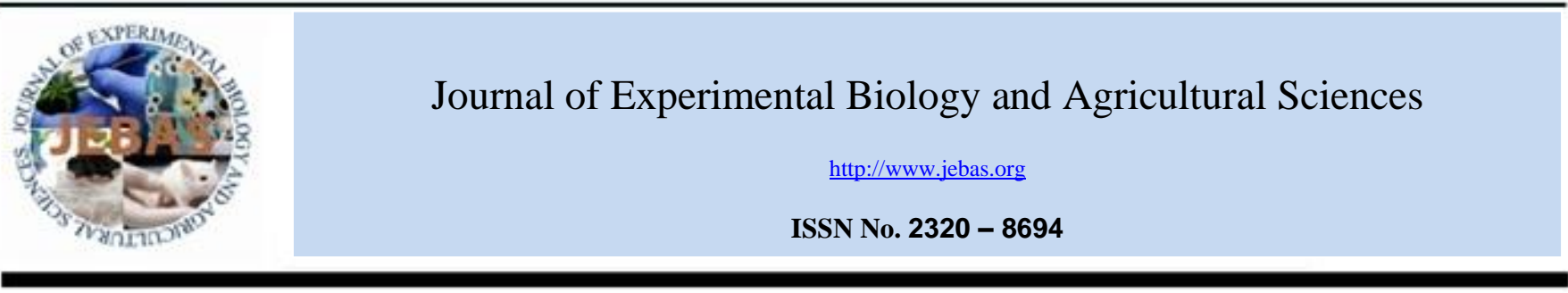

\title{
MOLECULAR IDENTIFICATION AND INTEGRATED MANAGEMENT OF THE Fusarium f. sp. cucumerinum THE CAUSAL AGENT OF Fusaruim WILT DISEASE OF Cucumis sativus L. IN IRAQ
}

\section{Safaa N. Hussein}

Assistant Lecturer, Environmental Engineering Department, Faculty of Engineering, Unv. of Al.Almustansiriyah, Baghdad, Iraq

Received - March 15, 2016; Revision - April 05, 2016; Accepted - May 21, 2016

Available Online - June 25, 2016

DOI: http://dx.doi.org/10.18006/2016.4(4).389.397

KEYWORDS
Fusarium oxysporum f. sp.
cucumerinum
Chaetomium cupreum
Trichoderma viride
Bacillus pumilus
Salicylic acid
Cucumber
PCR

\begin{abstract}
This study was aimed to isolate and identify the phytopathogenic fungus Fusarium oxysporum f. sp. cucumerinum (Foc) the causal agent of the Fusarium vascular wilt disease of cucumber in the middle and south of Iraq. The results of study indicated the presence of the pathogen with percentage of appearance $71.43 \%$ with frequency $46.43 \%$. Molecular identification carried out using polymerase chain reaction technique indicated the presence 18 isolates of Foc pathogenic group I and 6 isolate of Foc pathogenic group II. Among these, the isolate Foc-b3 was most virulent under in vitro pathogenicity test on the cucumber seed and it exhibited $0 \%$ seed germination compared with control. An attempt of integrated management of $F$. oxysporum $\mathrm{f}$. sp. сиситеrinum under in vitro conditions was also carried out in present study and a significant inhibition were reported on the application of various bioagents such as Chaetomium cupreum (Cc), Trichoderma viride (Tv) and Bacillus pumilus (Bp) on the potato dextrose agar (PDA). Further, under greenhouse conditions, combined application (tetrainoculums) of $\mathrm{Cc}+\mathrm{Tv}+\mathrm{Bp}+$ Salicylic acid $(\mathrm{Sa})$ was significantly reduced the percentage of the disease incidence and severity up to $0 \%$ as compared with the control where it was reported $97.50 \%, 75.72 \%$ respectively. Effect of this combination was also reported on the dry weight of the plants and significant improvement (0.975 gm/plant) was reported as compared to control (0.098 gm/plant).
\end{abstract}

* Corresponding author

E-mail: safaahussein03@gmail.com (Safaa N. Hussein)

Peer review under responsibility of Journal of Experimental Biology and Agricultural Sciences.

Production and Hosting by Horizon Publisher India [HPI] (http://www.horizonpublisherindia.in/).

All rights reserved.
All the article published by Journal of Experimental Biology and Agricultural Sciences is licensed under a Creative Commons Attribution-NonCommercial 4.0 International License Based on a work at www.jebas.org.

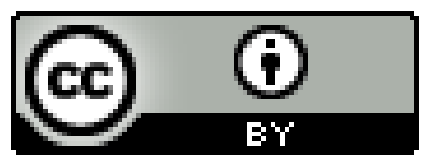




\section{Introduction}

Cucumber (Cucumis sativus L.) is an important vegetable crop throughout the world; it has similar importance in Iraq also (Saeed et al., 2015). Crop grown in various part of the country, and the area of cultivation reached 92.887 .00 ha with total production of 405.610 .00 ton in 2013 (FAO, 2015). In Iraq, crop production is affected by various physical and biological factors, among these serious economic losses was caused by Fusarium vascular wilt disease which is caused by the Fusarium oxysporum (Schlechtend.:Fr.) f. sp. cucumerinum (Owen) Snyder \& Hansen (Armstrong \& Armstrong, 1978). Foc is a host specific pathogen (Armstrong et al., 1978) and widely distributed in many cucumber grown areas such as South Africa, Japan, Thailand, England, France, Germany and Australasia (Booth, 1971; Plantwise, 2015). This disease was recorded first time on the cucumber in1951 (Zitter et al., 1996) while In Iraq, it was first time recorded in the province of Wasit in 2012 (Risan, 2012). Symptoms appear typically on the plant as foliar wilting, necrotic lesions of the stem base followed by vascular discoloration on the roots and stem (Vakalounakis, 1988; Vakalounakis et al., 2004). Three physiological races of the Foc viz 1, 2 and 3 have been identified (Armstrong et al., 1978). Information regarding molecular identification and characterization are in scarcity especially in context of Iraq.

Disease management is a major problem for cultivars; various chemical, physical, biological and cultural practices are carried out for the management of this disease. Among these, biological control offers an eco-friendly means of plant diseases management. Strategies of using beneficial microorganisms for controlling plant pathogens help in reducing the negative impacts of the chemicals on the environment and human health and it also cost effective (Higa, 1991; Parr \& Hornick, 1994). Various species such as Bacillus, Pseudomonas, Chaetomium, Trichoderma and Penicillium have been used widely in plant disease controlling (Vessey, 2003).Trichoderma species are widely used as biocontrol agents against plant pathogens since 1920s (Harman, 2006). Species belong to Chaetomium are normally found in the soil and organic compost, and has potential of cellulose and other organic materials degradation, species such as C. cupreum and C. globosum also has been proved to be good antagonistic agents against various plant pathogens (Soytong et al. 2001). Role of phytohormones such as Salicylic acid, Jasmonic acid, Abscisic acid and ethylene in inducing systemic resistance in plants against the broad range of the pathogens through activating plant enzymes such as peroxidase (POD) and polyphenol oxidase (PPO) has been well documented (War et al., 2011). This study was amid to investigate the occurrence of $F$. oxysporum f. sp. cucumerinum (Foc) in the middle and south of Iraq, isolated pathogens were identified by molecular identification technique. Further, effort of disease management by using eco-friendly means by using biocontrol agents $C$. cupreum, T. viride, B. pumilus and plant growth regulator Salicylic acid was also attempt.

\section{Materials and methods}

\subsection{Sampling, isolation and identification}

Samples were collected from various cucumber grown areas of Baghdad, Babil and Karbala provinces of Iraq during the growing season in 2014-2015. Infected samples were collected from rhizosphere and basal segment of the stem. Collected samples were washed by $1 \%$ Hypochlorite sodium for $1 \mathrm{~min}$ and cut off in to $0.5 \mathrm{~cm}$, disinfected sample were rinsed twice in sterile distilled water and dried. Four dried samples were incubated in laminar flow bench on Petri plat containing sterilized PDA (CDH Bioscience Co., India) and incubated at $25 \pm 2{ }^{\circ} \mathrm{C}$ for 7 days. Fungus grown around the infected segments were transferred individually on the separate PDA and incubated for 7 days at same temperature (Hussein \& Juber, 2015). Fungal isolates were identified according to the morphological characteristics described by (Booth, 1971; Booth 1977; Ellis, 1971; Domsch et al., 2007). Percentage of the appearance and frequency of the fungi calculated according to method of Hussein \& Juber (2014).

2.2 Identification of $F$. oxysporum f. sp. cucumerinum using specific polymerase chain reaction (PCR) assays

\subsubsection{DNA extraction}

DNA of the initially isolated 31 fungal isolates which basically identified as $F$. oxysporum based on the cultural and microscopic morphology characteristics were extracted using the fungal DNA extraction kit (EZ-10 Spin Column Fungal Genomic DNA Mini-Preps Kit, Bio Basic Inc., Canada) according to the manufacture instructions. For this all the isolates were purified by using single spore technique according to the method given by Hussein \& Juber (2015). Mycelium with spores were harvested by sterilized glass rod from each isolate individually and transferred into $1.5 \mathrm{ml}$ clean eppendorf tubes and kept in $-20{ }^{\circ} \mathrm{C}$ until DNA extraction process were established.

\subsubsection{Primers preparation}

Four specific primers used to identify $F$. oxysporum f. sp. cucumerinum pathogenic group I, II, III and IV (Bioneer Co., South Korea) (Table 1). Primers were diluted individually by adding sterile distilled water according to the company instructions to obtain the concentration of $100 \mathrm{pmol} / \mu \mathrm{l}$ and stored at $-20{ }^{\circ} \mathrm{C}$ until uses. 
Table 1 Specific primers and amplification conditions used in the PCR process.

\begin{tabular}{|l|lc|}
\hline \multicolumn{1}{|c|}{ primer of pathogenic group } & \multicolumn{1}{c|}{ Sequence $\left(5^{\prime} \rightarrow 3^{\prime}\right)$} & Annealing temp./ cycles \\
\hline I & F: AGGTGACCGTCGTAGCAAG & $54^{\circ} \mathrm{C} / 25$ \\
\cline { 2 - 3 } & R: AGGTGACCGTTGAGAGGA & $61{ }^{\circ} \mathrm{C} / 35$ \\
\hline II & F: GGAGGGTGTTGGAGATGC & $62{ }^{\circ} \mathrm{C} / 25$ \\
\cline { 2 - 3 } & R: GCAGGGTGTTACTCCAGGCAC & $55^{\circ} \mathrm{C} / 25$ \\
\hline III & F: GATGACCGCCAATGTGTACT & \\
\hline
\end{tabular}

$\mathrm{F}=$ Forward, $\mathrm{R}=$ Reverse (Najafiniya \& Sharma ,2011)

\subsubsection{Polymerase chain reaction (PCR) assays}

Extracted fungal DNA were amplified using standard master mix (AccuPower PreMix series, Bioneer Co., South Korea) in the PCR experiments, reaction mixture consist of $250 \mu \mathrm{M}$ each dNTP, $1.5 \mathrm{mM} \mathrm{MgCl} 2,30 \mathrm{mM}$ KCL, $10 \mathrm{Mm}$ Tris-HCL (pH 9.0), $1 \mathrm{U}$ Taq DNA polymerase, $1.5 \mu \mathrm{l}$ of each primer, $3 \mu 1$ DNA template in concentration of $50 \mathrm{ng} / \mu \mathrm{l}$ and $14 \mu \mathrm{l}$ sterile distilled water in eppendorf tube $0.2 \mathrm{ml}$, negative control were performed in all the experiments which was DNA template replaced with sterile distilled water, the quality and concentration of the DNA were tested using spectrophotometer (NanoSpec Cube, Nanolytic, Germany) at the wavelength 260/280 nm (Maniatis et al., 1982). Samples were enrolled into the Thermocycler (Model 480, Perkin-Elmer Co., USA), amplification program have been organized for each primer in similar conditions except annealing temperature step which was specific to each primer particular (Table 1) according to the method of Najafiniya \& Sharma (2011), each program started with 1 initial denaturation cycle at $95^{\circ} \mathrm{C}$ for $4 \mathrm{~min}$, followed by 25 cycles except with primer of pathogenic group II where it was 35 cycles, each cycle consist of denaturation step at $95^{\circ} \mathrm{C}$ for $1 \mathrm{~min}$, annealing step for $1 \mathrm{~min}$ at $54{ }^{\circ} \mathrm{C}, 61$ ${ }^{\circ} \mathrm{C}, 62{ }^{\circ} \mathrm{C}, 55{ }^{\circ} \mathrm{C}$ for the primer of pathogenic group I, II, III, IV respectively, and an extension step at $72^{\circ} \mathrm{C}$ for $2 \mathrm{~min}$, followed by 1 cycle final extension step at $72^{\circ} \mathrm{C}$ for $7 \mathrm{~min}$.

\subsubsection{Gel electrophoresis}

Amplification products were separated on the $1.5 \%$ agarose gel (Bio Basic Inc., Canada) by adding $1 \mathrm{gm}$ agarose to $100 \mathrm{ml}$ TBE buffer (Tris-Borate-EDTA, 10x solution, Bio Basic Inc., Canada) which is consist of 0.089 M Tris Base, $0.189 \mathrm{M}$ Boric Acid, 0.112 M EDTA after diluted to $1 \mathrm{x}$ by adding 10 $\mathrm{ml}$ TBE buffer to $90 \mathrm{ml}$ sterile distilled water and poured into agarose electrophorsis kit (Model AE-6100, ATTO Co., Japan), TBE buffer $x 1$ concentration 1:10 ( TBE: sterile distilled water) added to on the solid agarose gel in the agarose EP kit, $10 \mu 1$ of PCR products for each isolate individually and $2 \mu 1$ of green DNA dye (Bio Basic Inc., Canada) mixed and loaded into the holes of the agarose gel, $1 \mu \mathrm{l}$ of the $1 \mathrm{~kb}$ DNA ladder marker (Thermo Scientific, USA) mixed gently with 1 $\mu 1$ 6x DNA loading dye (Thermo Scientific, USA) and $4 \mu \mathrm{l}$ deionized water were loaded into the hole of the agarose gel as well as negative control. The gels were visualized under U.V. light using U.V. Transilluminator and Jell documentation system (Cleaver, UK).

\subsection{Pathogenicity test}

In-vitro pathogenicity test was conducted for the 31 isolated and purified fungal isolates of $F$. oxysporum, using filter paper technique. For this spore suspension were prepared by pouring $10 \mathrm{ml}$ of the sterile distilled water into fungal mycelium containing petri plate; mycelia were scraped by sterile glass rod and pour the liquid from the plate into the cheese cloth placed folded over a sterile conical flask. The spore suspension was prepared at $5 \times 10^{4}$ spore concentration by using sterile water and hemocytometer. Seeds of cucumber cultivar Green Paris (Vilmorin/ France) uncoated with fungicide were surface sterilized and 10 seeds were transferred into each petri plate $(9$ $\mathrm{cm}$ diameter) containing 5 layers of filter paper $(9 \mathrm{~cm}$ diameter), each plate were watered with $1 \mathrm{ml}$ spore suspension and $3 \mathrm{ml}$ sterile distilled water. All the plates were incubated at $25{ }^{\circ} \mathrm{C}$ for 14 days and watered as needed, each treatment has 4 replicates. Percentage of the seed germination was calculated according to the formula below:

The Percentage of germination $=\frac{\text { No. of seeds germinated }}{\text { Total No. of seeds }} \mathrm{X} 100$

\subsection{In vitro antagonism assay}

Antagonistic activity was conducted on the PDA medium by using dual culture technique with biocontrol fungi $C$. cupreum, $T$. viride and $B$. pumilus against the fungal isolate Foc-b3 according to the method of Lamsal et al. (2012). Among these, C. cupreum and B. pumilus was obtained from previous study while the fungus $T$. viride which obtained from Ministry of Science and Technology, Department of Agricultural Research, Iraq. A disc of $0.5 \mathrm{~cm}$ of PDA containing 7 days old pathogen was inculcated on the dual PDA plate $(9 \mathrm{~cm}$ diameter) about $2 \mathrm{~cm}$ apart from the plate edge and similar dice size of the bioagents $\mathrm{Tv}$ and $\mathrm{Cc}$ and $20 \mu \mathrm{l}$ of the bacteria Bp 
was inculcated individually on the opposite side of the plate about $2 \mathrm{~cm}$ apart from the plate edge, separate plates of PDA were amended as a control containing a disc of the pathogen only, all the plates were incubated at $28{ }^{\circ} \mathrm{C}$ for 10 days. Inhibition effect was calculated by measuring the distance of the fungal growth radius of the pathogen toward the bioagents compared with the control according to the following formula:

$$
\text { Inhibtion }(\%)=\frac{\mathrm{R}-\mathrm{r}}{\mathrm{R}} \times 100
$$

(Lamsal et al., 2012)

Where: $\mathrm{R}=$ is the radius of the pathogen in control plate, $\mathrm{r}=$ is the radius of the pathogen in dual culture plate.

2.5 Management of Fusarium wilt disease of cucumber under greenhouse conditions

Greenhouse study was conducted to evaluate the disease suppression and plant growth ability of selected bioagents Cc, $\mathrm{Tv}, \mathrm{Bp}$ and plant growth elicitor Sa (Merck Millipore Co., Germany) either individually or in combination. Inoculum of the fungal isolates of $\mathrm{Cc}, \mathrm{TV}$ and Foc-b3 were prepared by adding 5 disc $(0.5 \mathrm{~cm})$ of 7 days old fungal culture to the conical flask $(500 \mathrm{ml})$ containing $200 \mathrm{gm}$ autoclaved millet seeds (Pennisetum glaucum) and incubated at $25{ }^{\circ} \mathrm{C}$ for 14 days. Inoculum of the $\mathrm{Bp}$ was prepared on sterilized nutrient broth medium and incubated at $30{ }^{\circ} \mathrm{C}$ for 7 days with constant shaking, spore density amended to $10^{8} \mathrm{CFU}$. $\mathrm{ml}^{-1}$ by hemocytometer, while $\mathrm{Sa}$ solution was prepared at the concentration of $150 \mu \mathrm{g} \cdot \mathrm{ml}^{-1}$. Mixture of the autoclaved soil and compost (2:1) were filled into the plastic pots $(13 \mathrm{~cm}$ diameter), inoculum of the pathogen was added as $1 \%(w / w)$ to the pots and watered, three days after inculation, pots were planted with 10 seeds of the cucumber, in the same time 40 $\mathrm{ml} /$ pot of the Bp inoculum was added as soil drench, inoculum of $\mathrm{Cc}$ and $\mathrm{Tv}$ added as $1 \%(\mathrm{w} / \mathrm{w})$, the Sa solution was soil drenched as $40 \mathrm{ml} /$ pot after 10 days of seeds planting. Pots are arranged according to the completely randomized design (CRD) with 4 replicates in the greenhouse and watered as needed, percentage of seed germination calculated after 10 days. Percentage of disease incidence was calculated after 8 weeks of seed planting according to the formulas described by
Masood et al. (2010). Disease severity was estimated by using the score-rating chart below which is described by Schneider (1984) with simple modification: $0=$ No symptoms, $1=$ mild vascular discoloration in roots, $2=$ extensive vascular discoloration in roots, $3=$ mild discoloration in crown, $4=$ extensive discoloration in crown, $5=$ mild disintegration of crown and roots tissue, $6=$ extensive disintegration of crown and roots tissue, and $7=$ wilted or plant dead. The Percentage of disease severity index (DSI) was calculated by using the formula described by Grau \& Radke (1982). The dry weights of plants were also recorded during the study.

\section{Results and Discussion}

\subsection{Isolation and identification}

Results of the isolation study along with association number of fungi were indicated in (table 2). Among various isolated pathogenic fungi, $F$. oxysporum was predominant, and it exhibited $71.43 \%, 46.43 \%$ percentage of appearance and frequency respectively. Morphological characteristic of 7 days old Foc was white colony with a purple tinge, reverse pale purple pigment on the bottom of the plate, floccose texture, diameter ranched $4.5-5 \mathrm{~cm}$. The fungus formed small microconidia with oval shaped, ellipsoid, cylindrical, straight to curved with 1- 2 septate born on the simple phialides arising laterally on the hyphae or from short sparsely branched conidiophores, thin-walled macroconidia born on the branched conidiophores appeared as fusoid shaped with a definite foot cell with 3-5 septate, whilst terminal or intercalary chlamydospores were formed rarely with rough walled arranged solitary or in chains (Booth, 1971 ; Compbell et al., 2013).

3.2 Identification of $F$. oxysporum f. sp. cucumerinum using PCR assay

The PCR analyses of $F$. oxysporum were demonstrated that 24 isolates were belong to special form of $F$. oxysporum $\mathrm{f}$. sp. cucumerinum (table 3), among these 18 isolates were observed to amplify fragments with primer of the pathogenic group I and, their bands shown at $1.320 \mathrm{~kb}$ (Fig. 1).

Table 2 Fungi associated with the samples isolated from the collected root and shoot samples.

\begin{tabular}{|c|c|c|}
\hline Fungus name & Appearance (\%) & Frequency $(\%)$ \\
\hline Aspergillus niger Van Tieghem & 42.86 & 15.63 \\
\hline Cladosporium cladosporioides (Fresen.) G.A. de Vries & 28.57 & 18.30 \\
\hline Fusarium oxysporum Schlesht & 71.43 & 46.43 \\
\hline Fusarium solani (Mart.) Sacc. & 21.43 & 10.71 \\
\hline Pencillium sp. & 35.71 & 20.54 \\
\hline Phoma sp. & 14.29 & 4.91 \\
\hline Rhizctonia solani (Kuhn) & 7.14 & 2.23 \\
\hline Rhizopus sp. & 28.57 & 13.39 \\
\hline Ulocladium atrum Preuss & 14.29 & 3.13 \\
\hline
\end{tabular}


Table 3 Detection pathogenic group I, II, III and IV of F. oxysporum f. sp. cucumerinum using specific primers.

\begin{tabular}{|c|c|c|c|c|c|c|c|c|c|}
\hline \multirow[t]{2}{*}{ Isolate } & \multicolumn{4}{|c|}{ Primer } & \multirow[t]{2}{*}{ Isolate } & \multicolumn{4}{|c|}{ Primer } \\
\hline & I & II & III & IV & & I & II & III & IV \\
\hline Control & - & - & - & - & Foc-b9 & + & - & - & - \\
\hline Foc-g1 & + & - & - & - & Foc-b10 & - & + & - & - \\
\hline Foc-g2 & + & - & - & - & Foc-b11 & + & - & - & - \\
\hline Foc-g3 & - & + & - & - & Foc-b12 & + & - & - & - \\
\hline Foc-g4 & + & - & - & - & Foc-b13 & - & - & - & - \\
\hline Foc-g5 & + & - & - & - & Foc-k1 & - & - & - & - \\
\hline Foc-g6 & + & - & - & - & Foc-k2 & + & - & - & - \\
\hline Foc-g7 & + & - & - & - & Foc-k3 & - & - & - & - \\
\hline Foc-b1 & + & - & - & - & Foc-k4 & - & - & - & - \\
\hline Foc-b2 & - & - & - & - & Foc-k5 & - & + & - & - \\
\hline Foc-b3 & + & - & - & - & Foc-k6 & + & - & - & - \\
\hline Foc-b4 & + & - & - & - & Foc-k7 & - & - & - & - \\
\hline Foc-b5 & + & - & - & - & Foc-k8 & + & - & - & - \\
\hline Foc-b6 & - & + & - & - & Foc-k9 & - & - & - & - \\
\hline Foc-b7 & - & + & - & - & Foc-k10 & - & + & - & - \\
\hline Foc-b8 & + & - & - & - & Foc-k11 & + & - & - & - \\
\hline
\end{tabular}

Foc-1g - Foc-7g = Baghdad, Foc-1b - Foc-13b = Babil, Foc-1k - Foc-11k = Karbala

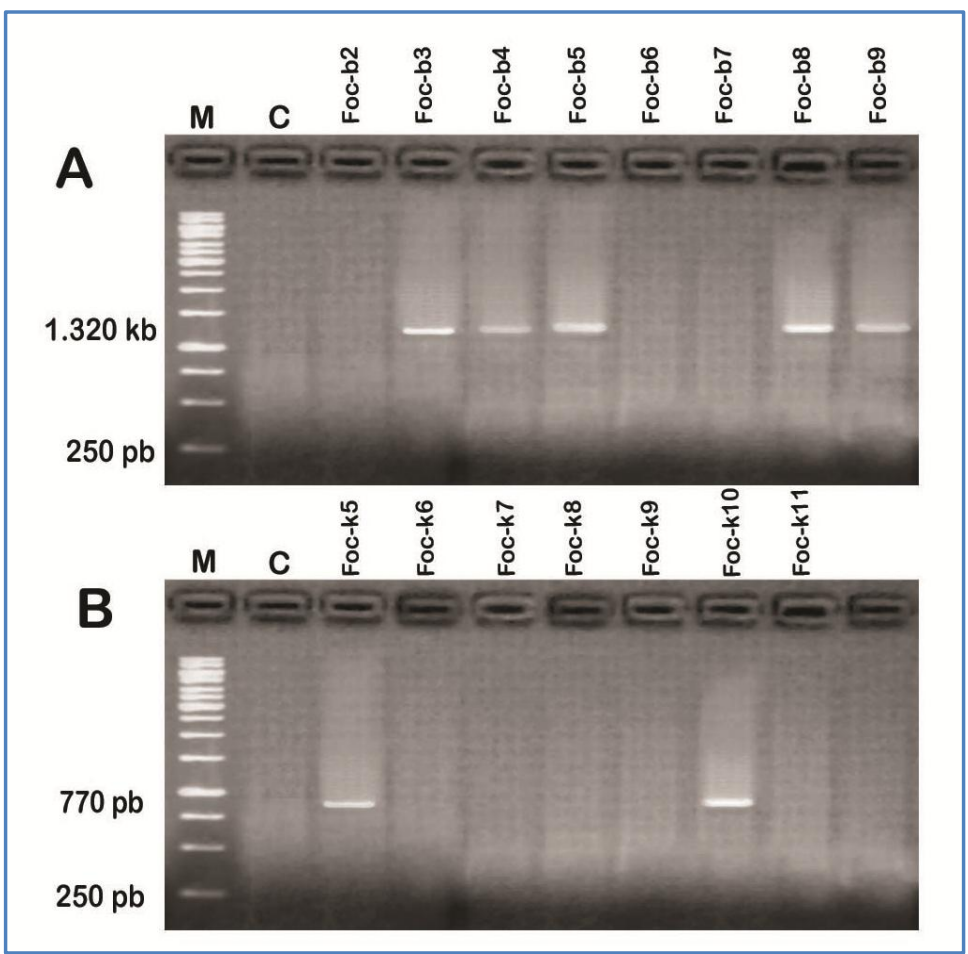

Figure $1 \mathrm{Gel}$ electrophoresis of the amplification product from PCR using genomic DNA of $F$. oxysporum f. sp. cucumerinum isolates using specific primers.

A. Primer of pathogenic group I, B. Primer of pathogenic group II, M. DNA ladder marker, C. Negative control. 
Table 4 Pathogenicity effect of $F$. oxysporum isolates to cucumber seeds.

\begin{tabular}{|c|ccc|}
\hline Isolate & Germination (\%) & Isolate & Germination (\%) \\
\hline Control & 100.0 & Foc-b9 & 30.0 \\
\hline Foc-g1 & 40.0 & Foc-b10 & 22.5 \\
\hline Foc-g2 & 35.0 & Foc-b11 & 30.0 \\
\hline Foc-g3 & 32.5 & Foc-b12 & 22.5 \\
\hline Foc-g4 & 37.5 & Foc-b13 & 60.0 \\
\hline Foc-g5 & 20.0 & Foc-k1 & 65.0 \\
\hline Foc-g6 & 35.0 & Foc-k2 & 22.5 \\
\hline Foc-g7 & 22.5 & Foc-k3 & 45.0 \\
\hline Foc-b1 & 20.0 & Foc-k4 & 47.5 \\
\hline Foc-b2 & 47.5 & Foc-k5 & 35.0 \\
\hline Foc-b3 & 5.0 & Foc-k6 & 32.5 \\
\hline Foc-b4 & 27.5 & Foc-k7 & 57.5 \\
\hline Foc-b5 & 15.0 & Foc-k8 & 25.0 \\
\hline Foc-b6 & 17.5 & Foc-k9 & 52.5 \\
\hline Foc-b7 & 42.5 & Foc-k10 & 15.0 \\
\hline Foc-b8 & 40.0 & Foc-k11 & 40.0 \\
\hline SEM Value $=1.7$ & \\
\hline LSD $(0.05)=3.4$ & \\
\hline
\end{tabular}

Each number reflects 4 replicates.

Six isolates amplified with primer of the pathogenic group II and, their bands were shown at 0.770 , while 7 isolates did not amplified with any of the four primers, it may be due to be these isolates belonging to other form or due to technical error.

\subsection{Pathogenicity test}

The 31 isolates of $F$. oxysporum showed variation in their pathogenicity, while the percentage of the seed germination was reported between $5-65 \%$ as compared to the control which shows $100 \%$ germination (table 4 ). Among all the tested isolates, Foc-b3 inhibit maximum seed germination and exhibited 5\% seed germination. Further, isolates belong to the province Babil showed higher pathogenicity than other two provinces; this variation in the pathogenic ability between the isolates may be refer to the genetic variation between races of the fungus or may be due to the geographical distribution, properties of the soil and environmental conditions.

\subsection{In vitro antagonism assay}

All the bioagents were effectively inhibited the mycelial growth of the pathogen on the PDA. In vitro comparison with the control (fungus alone) which filled the petri plate after 10 days of incubation (table 5), the bioagent $\mathrm{Tv}$ was superior which exhibited $82.69 \%$ percentage of inhibition this inhibition was followed by $\mathrm{Cc}$ and $\mathrm{Bp}$ where they exhibited $68.85 \%$, $66.92 \%$ inhibition respectively (Fig. 2). These results are in agreement with Fitsum et al. (2014) who obtained high percentage of inhibition $80.39 \%$ in dual culture plate of $T$. viride against Colletotrichum lindemuthianum in vitro.
Table 5 Inhibition effect of the bioagents against $F$. oxysporum in vitro.

\begin{tabular}{|l|l|}
\hline Treatment & Inhibition $(\%)$ \\
\hline Control & 0.0 \\
\hline Foc-b3 + TV & 82.69 \\
\hline Foc-b3 + Cc & 68.85 \\
\hline Foc-b3 + Bp & 66.92 \\
\hline LSD $(0.05)=0.65$ & \\
\hline
\end{tabular}

Foc-b3 $=F$. oxysporum f. sp. cucumerinum, $\quad \mathrm{Tv}=T$. viride, $\mathrm{Cc}=$ C. cupreum, $\mathrm{Bp}=$ B. pumilus

Each number reflects 4 replicates.

3.5 Management the Fusarium wilt disease of cucumber under greenhouse conditions

The results indicated that all of the treatments used in this experiment were positively increased the percentage of the seed germination, while the percentage ranged between 75 $100 \%$ compared with the negative control (Pathogen alone) which shows only $52.5 \%$ seed germination (table 6). Disease management ability of various treatments under greenhouse conditions varies and superiority was shown by the tetra inoculum containing $\mathrm{Tv}+\mathrm{Cc}+\mathrm{Bp}+\mathrm{Sa}$, treatment significantly reduced the percentage of disease incidence and severity up to $0 \%$ as compared with the negative control which shows $97.50 \% \& 72.75 \%$ respectively (Figure 3 ).

This combination was followed by the triinoculum of $\mathrm{Tv}+\mathrm{Bp}+$ Cc which exhibited $32.50 \%, 26.50 \%$ disease incidence and severity respectively. All of the treatments increased the dry weigh of the plants significantly, among these tetrainoculum shows superiority over the other treatments and exhibited $0.975 \mathrm{gm} /$ plant compared with the negative control which was $0.098 \mathrm{gm} /$ plant. These results are agreed with the results of other studies, such as Soytong \& Soytong (1997) where they found that the tomato plants treated with $C$. cupreum in the form of mycofungicide completely prevented the damages caused by $F$. oxysporum in Thailand. Similar types of results were obtained by John et al. (2010) those who reported that $T$. viride is an effective bioagent against the plant pathogens $F$. oxysporum and Pythium arrhenomanes in soybean trial. Further, they reported that $T$. viride not only controlled the pathogens but also simultaneously increased the plant growth and modified the rhizosphere of soybean plant.

The bioagents C. cupreum and T. viride suppressed the pathogen through several mechanisms including mycoparasitism, antibiosis and competition for space and nutrient resources. The mycoparasitism activity of the $T$. viride inducing its growth toward the pathogens, it creates coiling on the target fungi and induced inactivation of the pathogen's enzymes by producing several antifungal extracellular enzymes such as protease. 


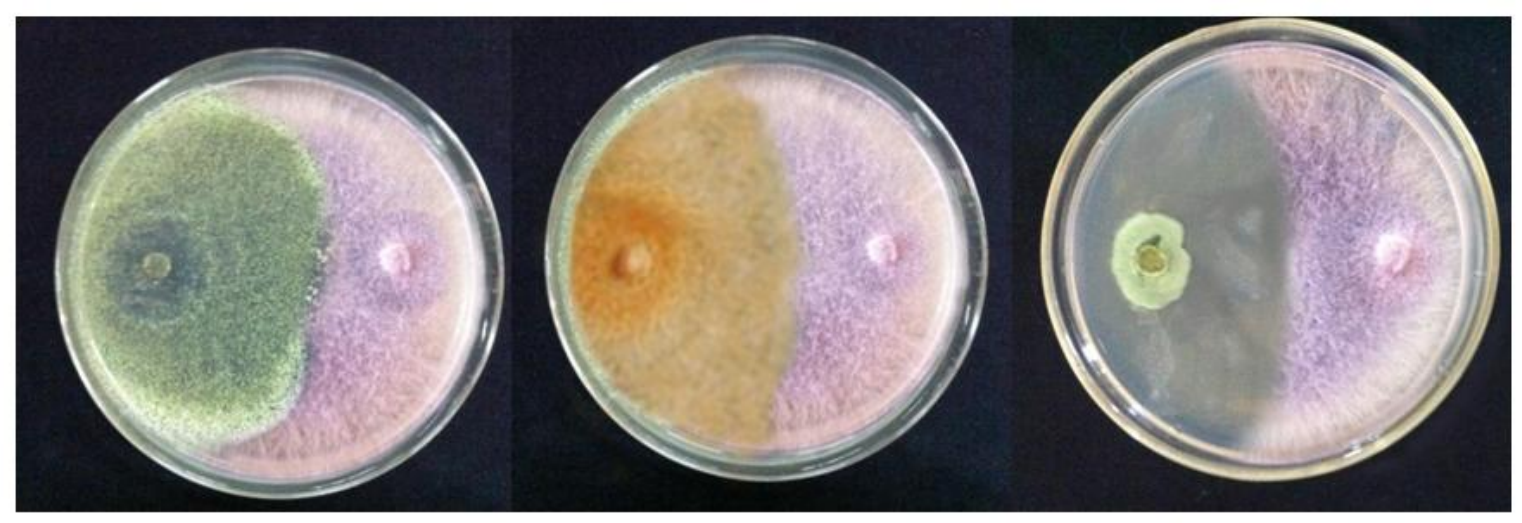

A

$\mathrm{C}$

Figure 2 Inhibition effect of the bioagents against $F$. oxysporum using dual culture method.
A.) $\mathrm{Tv}+$ Foc-b3,
B.) $\mathrm{Cc}+\mathrm{Foc}-\mathrm{b} 3$,
C.) Bp+Foc-b3

Further it was also reported that enzymes secreted from $T$. viride suppressed the enzymes produced by pathogens i.e. chitinase and glucanase. These biocontrol agents, also playing a big role in rhizosphere modification, biofertilization and stimolization of plant defense mechanisms (Harman, 2006). The soil bacteria $B$. pumilus also inhabiting in the rhizosphere microbial growth and acting as one of the PGPR group (Hussein \& Juber, 2015). This bacteria involved in promoting plant growth directly or indirectly through production of several regulatory chemicals in the rhizosphere area. The
PGPR generally enhance the plant growth directly through amending plant hormone or facilitate by resources such as phosphorus and nitrogen acquisition, and indirectly by the forms of biological control agents through suppression negative impact of the phytopathogens on plant growth development (Ahemed \& kibret, 2014). The phytohormone Salicylic acid is also performing an essential role in plant growth regulation and plant's reaction to the biotic and abiotic stresses by involving locally and systemically induced resistance (Halim et al. 2006).

Table 6 Effect of the bioagents on the Fusarium wilt disease of the cucumber under greenhouse conditions.

\begin{tabular}{|c|c|c|c|c|c|}
\hline No. & Treatment & Germination (\%) & Incidence $(\%)$ & Severity $(\%)$ & Dry weight (gm/plant) \\
\hline 1 & Control & 100.0 & 0.0 & 0.00 & 0.396 \\
\hline 2 & Foc- $3 b+\mathrm{Tv}$ & 80.0 & 60.0 & 51.25 & 0.301 \\
\hline 3 & Foc $-3 b+C c$ & 77.5 & 67.5 & 56.50 & 0.230 \\
\hline 4 & Foc $-3 b+B p$ & 82.5 & 67.5 & 50.75 & 0.290 \\
\hline 5 & Foc- $3 b+\mathrm{Sa}$ & 75.0 & 70.0 & 62.00 & 0.129 \\
\hline 6 & Foc- $3 b+\mathrm{Tv}+\mathrm{Cc}$ & 100.0 & 50.0 & 30.00 & 0.378 \\
\hline 7 & Foc $-3 b+T v+B p$ & 100.0 & 52.5 & 41.50 & 0.404 \\
\hline 8 & Foc $-3 b+\mathrm{Tv}+\mathrm{Sa}$ & 87.5 & 55.0 & 43.00 & 0.398 \\
\hline 9 & Foc $-3 b+\mathrm{Tv}+\mathrm{Cc}+\mathrm{Bp}$ & 100.0 & 32.5 & 26.50 & 0.562 \\
\hline 10 & $\mathrm{Foc}-3 \mathrm{~b}+\mathrm{Tv}+\mathrm{Cc}+\mathrm{Sa}$ & 97.5 & 35.0 & 28.25 & 0.497 \\
\hline 11 & $\mathrm{Foc}-3 \mathrm{~b}+\mathrm{Tv}+\mathrm{Cc}+\mathrm{Bp}+\mathrm{Sa}$ & 100.0 & 0.0 & 0.00 & 0.975 \\
\hline 12 & Foc- $3 b+C c+B p$ & 95.0 & 45.0 & 33.00 & 0.317 \\
\hline 13 & Foc $-3 b+C c+S a$ & 95.0 & 47.5 & 41.25 & 0.249 \\
\hline 14 & Foc $-3 b+B p+S a$ & 92.5 & 65.0 & 56.25 & 0.312 \\
\hline 15 & Tv & 100.0 & 0.0 & 00.00 & 0.550 \\
\hline 16 & $\mathrm{Cc}$ & 100.0 & 0.0 & 00.00 & 0.502 \\
\hline 17 & $\mathrm{Bp}$ & 100.0 & 0.0 & 00.00 & 0.587 \\
\hline 18 & $\mathrm{Sa}$ & 100.0 & 0.0 & 00.00 & 0.418 \\
\hline 19 & Foc-3b & 52.5 & 97.5 & 72.75 & 0.098 \\
\hline & SEM Value & 7.3 & 9.4 & 10.53 & 0.114 \\
\hline & $\operatorname{LCD}(0.05)$ & 14.7 & 18.9 & 21.09 & 0.229 \\
\hline
\end{tabular}

Each number reflects 4 replicates. 


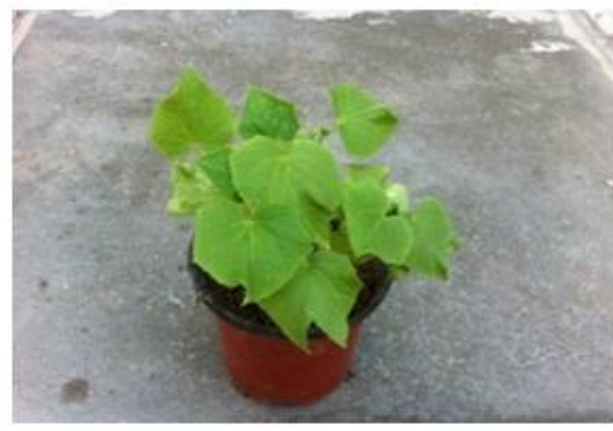

A

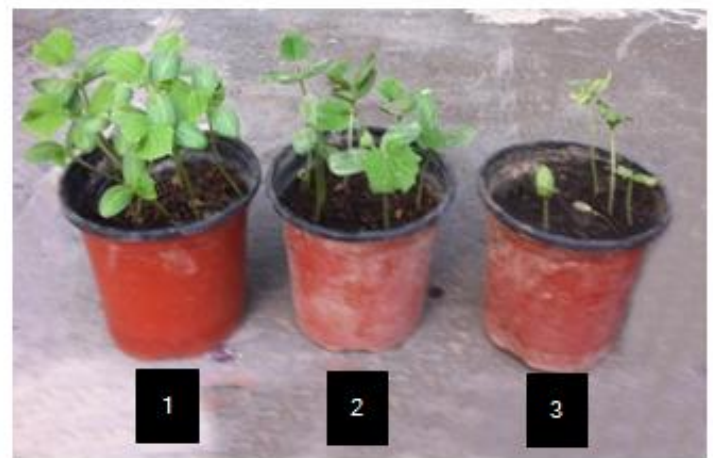

\section{$\mathrm{C}$}

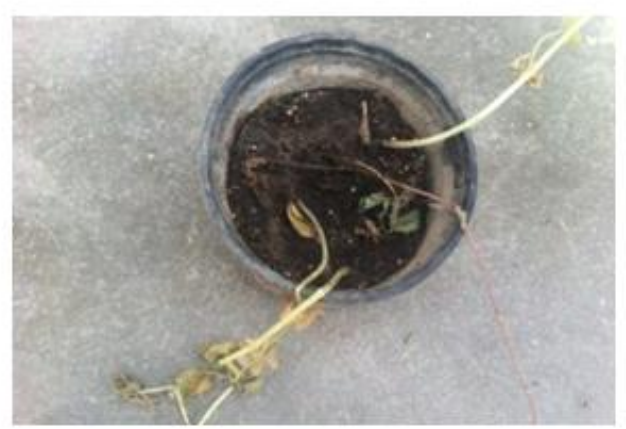

B

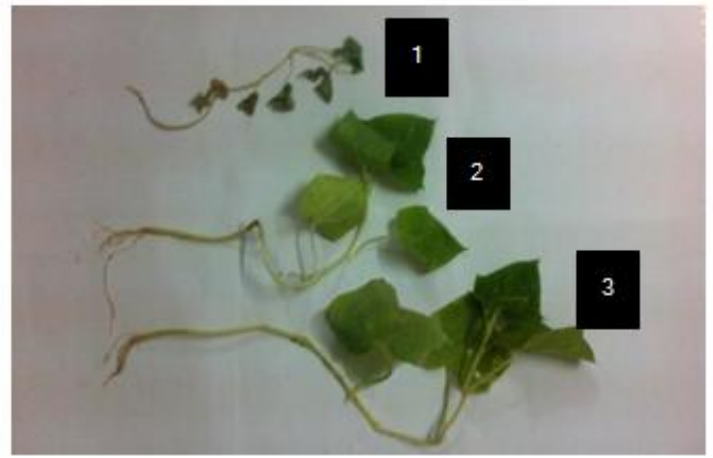

D

Figure 3 Fusarium wilt disease control under greenhouse condition.

$\mathrm{A}=$ Tetrainoculum of $(\mathrm{Tv}+\mathrm{Cc}+\mathrm{Bp}+\mathrm{Sa}), \mathrm{B}=$ Negative control $($ Foc-b3), $\mathrm{C}=1$. Tetrainoculum of $(\mathrm{Tv}+\mathrm{Cc}+\mathrm{Bp}+\mathrm{Sa}), 2 . \mathrm{Control}, 3$. Negative control. $\mathrm{D}=1$. Negative control, 2. Control, 3. Tetrainoculum of $(\mathrm{Tv}+\mathrm{Cc}+\mathrm{Bp}+\mathrm{Sa})$.

\section{Conflict of interest}

Authors would hereby like to declare that there is no conflict of interests that could possibly arise.

\section{References}

Ahemed M, Kibret M (2014) Mechanisms and applications of plant growth promoting rhizobacteria: Current perspective, Journal of King Saud University - Science 26: 1-20. doi:10.1016/j.jksus.2013.05.001

Armstrong GM, Armstrong JK (1978) Formae speciales and races of Fusarium oxysporum causing wilts of the Cucurbitaceae. Phytopathology 68:19-28.

Armstrong GM, Armstrong JK, Netzer D (1978) Pathogenic races of the cucumber-wilt Fusarium. Journal of Plant Disease 62:824-828.

Booth C (1971) The Genus Fusarium, Commonwealth Mycological Institute, Kew, Surrey, UK, Pp. 237.

Booth C (1977) Fusarium: Laboratory Guide to the Identification of the Major Species. Commonwealth Mycological Institute, Kew, Surrey, UK, Pp.58.
Compbell CK, Johnson EM, Warnock DW (2013) Identification Pathogenic Fungi, 2nd edition. Blackwell Publishing, John Wiley \& Sons, Ltd., Publication, UK, Pp. 174- 175 .

Domsch KH, Gams W, Anderson T (2007) Compendium of Soil Fungi, 2nd edition. IHW-Verlag, Eching, Pp. 672.

Ellis MB (1971) Dematiaceous Hyphomycetes. Commonwealth Mycological Institute, Surrey, Kew, U.K. Pp. 608.

FAO (2015) Online, Food and Agriculture Organization. FAOSTAT. Available on: http://faostat3.fao.org/download/Q/QC/E/ access on 2015.

Fitsum S, Amin M, Selvaraj T, Alemayehu A (2014) In vitro evaluation of some fungicide and bioagents against common bean anthracnose (Colletotricum lindemuthianum Sacc. \& Magnus) Briosi \& Cavara. African Journal of Microbiology Research 8 : 2000-2005. doi:10.5897/AJMR2014.6825

Grau CR, Radke VL (1982) Resistance of soybean cultivar to Sclerotinia sclerotiorum. Journal of Plant disease 66 : 506-508. 
Halim VA, Vess A, Scheeland D, Rosahl S (2006) The role of salicylic acid and jasmonic acid in pathogen defence. Plant Biology 8 : 307-313.

Harman GE (2006) Overview of mechanisms and uses of Trichoderma spp. Phytopathology 96:190-194. doi: 10.1094/PHYTO-96-0190

Higa T (1991) Effective microorganisms: A biotechnology for mankind. In: Parr JF, Hornick SB, Whitman CE (Eds.) Proceedings of the First International Conference on Kyusei Nature Farming, Khon Kaen University, Thailand held on 17 21st October, 1989. U.S. Department of Agriculture, Washington, D.C., USA.

Hussein S, Juber K (2014) First report of identification Fusarium solani f. sp. cucurbitae race 1 and 2 the causal agent of crown and root rot disease of watermelon in Iraq. International Journal of Agriculture Innovation and Research 3 : 974-978.

Hussein S, Juber K (2015) Identification of the causal agent of crown and root rot disease of watermelon and evaluation the efficiency of the PGPR in controlling the disease under greenhouse conditions. The Iraqi Journal of Agricultural Sciences. 46: 11-20.

John R, Tyagi R, Prevost D, Satinder K, Pouleurand S, Surampalli R (2010) Mycoparasitic Trichoderma viride as a biocontrol agent against Fusarium oxysporum f. sp. adzuki and Pythium arrhenomanesand as a growth promoter of soybean. Crop Protection 29: 1452-1459. doi: 10.1016/j.cropro.2010.08.004.

Lamsal K, Lim S, Kum Y Lee Y (2012) Application of rhizobacteria for plant growth promotion effect and biocontrol of anthracnose caused by Colletotrichum acutatum on pepper. Mycobiology 40: 244-251. doi: 10.5941/MYCO.2012.40.4.244.

Maniatis T, Fritsch EF, Sambrook J (1982) Molecular Cloning: A Laboratory Manual. Cold Spring Harbor Laboratory, Cold Spring Harbor, NY, USA. Pp. 545.

Masood A, Saeed S, Iqbal N (2010) Methodology for the evaluation of symptoms severity of mango sudden death syndrome in Pakistan. Pakistan Journal of Botany 42: 12891299.

Najafiniya M, Sharma P (2011) Specific PCR-based marker for detection of pathogenic groups of Fusarium oxysporum f. sp. cucumerinum in India. Journal of Genetic Engineering and Biotechnology 9: 30-34. doi:10.1016/j.jgeb.2011.05.009.

Parr JF, Hornick SB (1994) Assessment of the Third International Conference on Kyusei Nature Farming: Round
Table Discussion by USDA Scientists, October 7, 1993. Published by the Nature Farming Research and Development Foundation, Lompoc, California, USA.

Plantwise Khnowldge Bank (2015) Available on http://www.plantwise.org/KnowledgeBank/Datasheet.aspx?dsi $\mathrm{d}=24622$ access on 2016.

Risan MH (2012) Diagnosis of Fusarium oxysporum fungus isolations and evaluation of the efficiency of the bacteria Bacillus subtilis and potassium phosphate in the inhibition of fungi F. oxysporum f. sp. cucumerinum and F. oxysporum f.sp. melonis. Iraqi Journal of Science 53:513-523.

Saeed KS, Ahmed SA, Ahmed PH (2015) Effect of biofertilizer and chemical fertilizer on growth and yield in cucumber (Cucumis sativus) in greenhouse condition. Pakistan Journal of Biological Sciences 18: 129-134. doi: 10.3923/pjbs.2015.129.134.

Schneider RW (1984) Effects of nonpathogeneic strains of Fusarium oxysporum on celery root infection by Fusarium oxysporum f. sp. apii and a novel use of the Lineweaver-Burk double reciprocal plot technique. Phytopathology 74: 646-653.

Soytong K, Kanokmedhakul S, Kukongviriyapa V, Isobe M (2001) Application of Chaetomium species (Ketomium ${ }^{\circledR}$ ) as a new broad spectrum biological fungicide for plant disease control: A review article. Fungal Diversity 7: 1-15.

Soytong K, Soytong K(1997) Chaetomium as a new broad spectrum mycofungicide. Proceedings of the First International Symposium on Biopesticides, Naresuan University, Pitsanulok, Thailand held on 27th - 31st October, 1997, Pp. 124-132.

Vakalounakis DJ (1988) Diseases and Pests of Vegetable Crops and Their Control. Technological Education Institute. Heraklio, Crete, Greece, Pp. 108.

Vakalounakis DJ, Wang Z, Fragkiadakis GA, Skaracis GN (2004) Characterization of Fusarium oxysporum isolates obtained from cucumber in China by pathogenicity, VCGs and RAPD. Plant Disease 88: 645-649.

Vessey JK (2003) Plant growth promoting rhizobacteria as Biofertilizers. Plant and Soil 255: 571-586. doi: 10.1023/A:1026037216893.

War AR, Paulraj MG, War MY Ignacimuthu S (2011) Role of salicylic acid in induction of plant defense system in chickpea (Cicer arietinum L.). Plant Signal \& Behavior 6: 1787-1792. DOI: $10.4161 /$ psb.6.11.17685

Zitter TA, Hopkins DL, Thomas CE (1996) Compendium of Cucurbit Diseases. American Phytopathological Society, St. Paul, MN, USA. Pp.11-17. 